\title{
Interannual variability in the peatland-atmosphere carbon dioxide exchange at an ombrotrophic bog
}

\author{
Peter M. Lafleur, ${ }^{1}$ Nigel T. Roulet, ${ }^{2}$ Jill L. Bubier, ${ }^{3}$ Steve Frolking, ${ }^{4}$ and Tim R. Moore ${ }^{2}$ \\ Received 11 September 2002; revised 5 December 2002; accepted 17 January 2003; published 19 April 2003.
}

[1] Eddy covariance measurements of net ecosystem carbon dioxide $\left(\mathrm{CO}_{2}\right)$ exchange

(NEE) were taken at an ombrotrophic bog near Ottawa, Canada from 1 June 1998 to 31 May

2002. Temperatures during this period were above normal except for 2000 and

precipitation was near normal in 1998 and 1999, above normal in 2000, and well below normal in 2001. Growing period maximum daytime uptake $\left(-0.45 \mathrm{mg} \mathrm{CO}_{2} \mathrm{~m}^{-2} \mathrm{~s}^{-1}\right)$ was similar in all years and nighttime maximum respiration was typically near $0.20 \mathrm{mg}$ $\mathrm{CO}_{2} \mathrm{~m}^{-2} \mathrm{~s}^{-1}$, however, larger values were recorded during very dry conditions in the fourth year of study. Winter $\mathrm{CO}_{2}$ flux was considerably smaller than in summer, but persistent, resulting in significant accumulated losses $\left(119-132 \mathrm{~g} \mathrm{CO}_{2} \mathrm{~m}^{-2}\right.$ period $\left.{ }^{-1}\right)$. This loss was equivalent to between 30 and $70 \%$ of the net $\mathrm{CO}_{2}$ uptake during the growing season. During the first 3 years of study, the bog was an annual sink for $\mathrm{CO}_{2}(\sim-260 \mathrm{~g}$ $\left.\mathrm{CO}_{2} \mathrm{~m}^{-2} \mathrm{yr}^{-1}\right)$. In the fourth year, with the dry summer, however, annual NEE was only $-34 \mathrm{~g} \mathrm{CO}_{2} \mathrm{~m}^{-2} \mathrm{yr}^{-1}$, which is not significantly different from zero. We examined the performance of a peatland carbon simulator (PCARS) model against the tower measurements of NEE and derived ecosystem respiration (ER) and photosynthesis (PSN). PCARS ER and PSN were highly correlated with tower-derived fluxes, but the model consistently overestimated both ER and PSN, with slightly poorer comparisons in the dry year. As a result of both component fluxes being overestimated, PCARS simulated the tower NEE reasonably well. Simulated decomposition and autotrophic respiration contributed about equal proportions to ER. Shrubs accounted for the greatest proportion of PSN (85\%); moss PSN declined to near zero during the summer period due to surface drying. INDEX TERMS: 0315 Atmospheric Composition and Structure: Biosphere/atmosphere interactions; 1615 Global Change: Biogeochemical processes (4805); 1890 Hydrology: Wetlands; KEYWORDS: peatland, bog, net ecosystem exchange, eddy covariance, carbon dioxide

Citation: Lafleur, P. M., N. T. Roulet, J. L. Bubier, S. Frolking, and T. R. Moore, Interannual variability in the peatland-atmosphere carbon dioxide exchange at an ombrotrophic bog, Global Biogeochem. Cycles, 17(2), 1036, doi:10.1029/2002GB001983, 2003.

\section{Introduction}

[2] Long-term studies of ecosystem carbon dioxide $\left(\mathrm{CO}_{2}\right)$ exchange improve our understanding of the links between climate and the carbon (C) cycle. It is important that we continue to develop such understanding for all major terrestrial ecosystems in order to resolve current uncertainties in $\mathrm{C}$ cycling and the global $\mathrm{C}$ budget [Canadell et al., 2000; Baldocchi et al., 2001]. In forested ecosystems, where the majority of research has been conducted, seasonal and

\footnotetext{
${ }^{1}$ Department of Geography, Trent University, Peterborough, Ontario, Canada.

${ }^{2}$ Department of Geography, Center for Climate and Global Change Research, McGill University, Montreal, Quebec, Canada.

${ }^{3}$ Environmental Studies Program, Department of Earth and Environment, Mount Holyoke College, South Hadley, Massachusetts, USA.

${ }^{4}$ Institute for the Study of Earth, Oceans, and Space, University of New Hampshire, Durham, New Hampshire, USA.
}

Copyright 2003 by the American Geophysical Union. 0886-6236/03/2002GB001983\$12.00 annual variations in $\mathrm{C}$ exchange have been linked to a number of climate related effects. For instance, climatedriven controls on ecosystem respiration (ER) can affect the annual $\mathrm{CO}_{2}$ balance, as has been shown for Harvard Forest [Goulden et al., 1998; Barford et al., 2001]. Variations in productivity, as affected by temperature control on the timing of the spring leaf-out, can also determine differences in forest annual net $\mathrm{C}$ exchange, such as in boreal deciduous stands [Black et al., 2000].

[3] Peatlands occupy only about $5 \%$ of the terrestrial surface, but may play an important role in the global C budget [Gorham, 1991; Schindler, 1999]. Compared to upland ecosystems, such as forests and grasslands, peatlands tend to have a smaller standing biomass, are less floristically diverse, are often nutrient poor, and have lower respiration rates and photosynthetic capacity [Thormann and Bayley, 1997; Frolking et al., 1998]. Although C accumulation rates are relatively slow in these diverse landscapes, historically $15-30 \mathrm{~g} \mathrm{C} \mathrm{m}^{-2} \mathrm{yr}^{-1}$ over millennial timescales, accumulation during the past 5000-10,000 
years has created a pool of soil $\mathrm{C}$ in peatlands of between 300 and $500 \mathrm{Pg} \mathrm{C}$, up to one-third of the total terrestrial soil C [Gorham, 1991; Turunen et al., 2002].

[4] Since there have been only few studies of $\mathrm{C}$ exchange on peatlands, little is known about the effects of large-scale environmental forcing on the peatland $\mathrm{C}$ balance. Studies on the $\mathrm{C}$ budget of peatlands to date have employed a variety of techniques, including environmentally controlled enclosures [e.g., Whiting, 1994; Bubier et al., 1998; Waddington and Roulet, 2000], flux gradient methods [Schreader et al., 1998], and eddy covariance [Nieveen et al., 1998; Lafleur et al., 1997, 2001a; Aurela et al., 2001]. Most studies have taken place in the growing season only. On a growing season basis, some peatlands have been net sources of $\mathrm{CO}_{2}$ [Lafleur et al., 1997; Schreader et al., 1998; Nieveen et al., 1998] whereas others have been net sinks [Suyker et al., 1997; Vourlitis and Oechel, 1997; Aurela et al., 2001; Lafleur et al., 2001a, 2001b]. Other studies have showed that a peatland was a net $\mathrm{CO}_{2}$ sink in the growing season of one year and a net source in the next year [Shurpali et al., 1995; Joiner et al., 1999; Griffis et al., 2000]. In addition, seasonal studies which exclude winter $\mathrm{CO}_{2}$ losses may well involve the conversion from seasonal sinks to annual sources of $\mathrm{CO}_{2}$ [Fahnestock et al., 1999; Oechel et al., 2000; Aurela et al., 2001; Lafleur et al., 2001a]. Thus in order to improve our understanding of peatland-atmosphere $\mathrm{C}$ exchange, more studies of annual $\mathrm{CO}_{2}$ budget on peatland ecosystems are needed.

[5] We investigate variations in annual and seasonal $\mathrm{CO}_{2}$ exchange at the Mer Bleue Bog in southern Canada, where eddy covariance measurements have been made since 1998 . The primary objective was to examine seasonal and annual variations in net ecosystem $\mathrm{CO}_{2}$ exchange (NEE) and to relate these variations to environmental conditions. In particular, because a wide range in conditions occurred during the study, we are able to investigate peatland $\mathrm{CO}_{2}$ flux response to a large range in summer moisture and winter snow cover and soil temperature conditions. A secondary objective was to evaluate a recently developed peatland carbon simulator (PCARS) [Frolking et al., 2002] against the tower measurements under a wide range of conditions.

\section{Study Site}

[6] The Mer Bleue bog is located in the Ottawa River Valley, just east of Ottawa, Ontario, Canada $\left(45.40^{\circ} \mathrm{N}\right.$ lat., $75.50^{\circ} \mathrm{W}$ long.). It lies in a postglacial channel system that was eroded into the floor of the former Champlain Sea basin. Inception of a fen phase from the preceding shallow lake occurred circa 8500 years BP, with the bog phase starting circa 6000 years BP. The climate of the region is cool continental, with a mean annual temperature of $5.8^{\circ} \mathrm{C}$ and an annual precipitation of $910 \mathrm{~mm}$ (1961-1990 normals). The coldest month is January $\left(-10.8^{\circ} \mathrm{C}\right)$ and the warmest month is July $\left(20.8^{\circ} \mathrm{C}\right)$. On average, $77 \%$ of the annual precipitation falls as rain; average growing season (May to September) precipitation is $410 \mathrm{~mm}$.

[7] Mer Bleue is a large ombrotrophic (nutrients fed only by rain) bog, approximately 2800 ha in area. Roughly oval shaped with an east-west orientation; two longitudinal lobes of fluvial sand/gravel material creating three separate arms of the bog dissect the western end. The research site is located in the northern most of these arms and has access from a road running along the gravel deposit. In this section, the bog is slightly domed toward the middle with peat depths varying from 5 to $6 \mathrm{~m}$ near the tower site and decreasing to about $2 \mathrm{~m}$ at the edge where a series of small ponds have formed creating a moat around the bog. The bog surface around the instrument site has a hummock-hollow microtopography, with mean relief between hummock tops and the hollow bottoms of $0.25 \mathrm{~m}$. Hummocks compose $70 \%$ of the surface and have a median diameter of about 1.0 $\mathrm{m}$. The water table is usually at or below the bottom of the hollows and it can vary considerably within the growing season.

[8] Details on the vegetation characteristics and sampling procedures at Mer Bleue can be found in the work of Moore et al. [2002] and Bubier et al. [2003]. The dominant vascular vegetation is low growing evergreen ericaceous shrubs, Chamaedaphne calyculata, Ledum groenlandicum, Kalmia augustifolium, and the deciduous shrub Vaccinium myrtilloides. The shrub canopy is between 20 and $30 \mathrm{~cm}$ in height, and the total leaf area index (one-sided) of the shrubs is about 1.3. A sparse cover of sedges (Eriophorum vaginatum) is present on hummocks, but was not included in the leaf area index (LAI) calculation. Trees (Picea mariana, Larix laricina, Betula papyrifera) exist on parts of the bog, but are largely absent from the study site. The ground cover on both hummocks and hollows is Sphagnum moss (Sphagnum capillifolium, Sphagnum fuscum, Sphagnum magellanicum). Total aboveground and belowground biomass averaged $356 \pm 100$ and $1820 \pm 660 \mathrm{~g} \mathrm{~m}^{-2}$ for vascular species and $144 \pm 30 \mathrm{~g} \mathrm{~m}^{-2}$ for the Sphagnum capitula [Moore et al., 2002].

\section{Measurements}

[9] The main instrument site was an 8-m tower located $250 \mathrm{~m}$ from the south edge of the bog accessed by a boardwalk. Along the boardwalk $15 \mathrm{~m}$ south of the tower were two small huts for storage and instrumentation. The huts were supplied with $120 \mathrm{~V} \mathrm{~A} / \mathrm{C}$ line power. Most instrumentation was located on the tower or within a 10 $\mathrm{m}$ radius of the huts. Fetch surrounding the tower site was limited only to the south $(200-300 \mathrm{~m})$; for all other bearings fetch ranged from 500 to $>1500 \mathrm{~m}$.

\subsection{Eddy Flux Measurements}

[10] The eddy covariance technique was used to measure the fluxes of $\mathrm{CO}_{2}$, heat, and water vapor. The system consisted of a three-dimensional sonic anemometer (model 1012R2 Solent, Gill Instruments, England), a closed-path infrared gas analyzer (IRGA, model 6262, LI COR, Lincoln, Nebraska, USA), fine wire thermocouple $(25 \mu \mathrm{m}$ diameter), and a krypton hygrometer (model KH20, Campbell Scientific, Logan, UT, USA). These instruments were mounted on the instrument tower at a height of $3.0 \mathrm{~m}$ from the mean elevation of the hummock tops on a boom $50 \mathrm{~cm}$ long oriented into the prevailing wind direction (northwest). 
Signals from all instruments were logged on a data logger (model CR7X, Campbell Scientific, Logan, UT, USA) with a scan rate of $10 \mathrm{~Hz}$ and fluxes computed every $30 \mathrm{~min}$ from two 15 min subsampling intervals using the data logger covariance program.

[11] The $\mathrm{CO}_{2}$ system was originally configured such that the IRGA was located in the main instrument hut. Air was drawn from an inlet mounted beside the sonic anemometer and traveled down a $16.5 \mathrm{~m}$ sample tube $(6.35 \mathrm{~mm}$ ID Beva-line) to the hut at $201 \mathrm{~min}^{-1}$. The sample line was wrapped with insulation from the intake to the hut. Inside the hut, the main flow was split and a subsample of the flow was bled off at $4.51 \mathrm{~min}^{-1}$ through a particle filter (Gelman $1 \mu \mathrm{m}$ pore size) into the IRGA. Pressure and temperature were measured in the air stream upon immediately leaving the IRGA sample cell. The air then passed through a mass flow controller (model FMA 1400, Omega Eng., USA) before merging with the main flow in a 1-1 baffle immediately before entering the pump. Travel time for the air from the inlet to the IRGA was measured frequently in manual tests [see Lafleur et al., 2001a] and found to be $2.2 \pm 0.1 \mathrm{~s}$. Programming in the data logger was used to account for this time lag. For flux measurements, the signal from the IRGA nonlinear voltage was used. The IRGA DAC output was logged to monitor absolute $\mathrm{CO}_{2}$ concentration, but not used for flux calculations.

[12] The configuration of the $\mathrm{CO}_{2}$ measurement system was altered in the fall 2000 when the IRGA and flow control system were relocated to an insulated, temperature-controlled box placed near the base of the tower. The main reason for this was to deploy a smaller suction pump and decrease the travel time for air from the inlet to the IRGA. The sample tube length was decreased to $6 \mathrm{~m}$, $2.5 \mathrm{~m}$ of which was coiled inside the heated box. The result of this change was that the lag time decreased to $1.4 \pm 0.1 \mathrm{~s}$.

[13] The IRGA was calibrated frequently using standard gases. The zero was checked using high-purity $\mathrm{N}_{2}$ gas and the span was set using high- and low- $\mathrm{CO}_{2}$ concentrations of 408 and 345 ppmv, respectively. At each calibration, the nonlinear voltage difference between the high and low spans was recorded and entered into the logger to provide a conversion slope (ppmv $\mathrm{mV}^{-1}$ ) for the raw IRGA output. This slope value was remarkably constant, varying less than $2 \%$ for all calibrations.

[14] Computation of the $\mathrm{CO}_{2}$ eddy flux $\left(F_{e}\right)$ was completed as follows. The covariance of the IRGA nonlinearized voltage and vertical wind speed was first converted to a flux using the concentration slope noted above. The flux was then corrected for pressure changes in the flow through the IRGA as it drifted from the pressure at calibration (usually less than 5\%). Finally, in a postprocessing procedure the Webb correction for fluctuation in water vapor effects on density of air was applied [Webb et al., 1980]. The correction for sensible heat flux was not applied as it was assumed that temperature fluctuations were dampened because of the length of sampling tube, and in the later configuration, due to heating of the sample line before entering the IRGA. A two-dimensional coordinate rotation applied to the sensible and latent heat fluxes resulted in a small $(0-2.5 \%)$ correction. Program and memory limita- tions in the data logger precluded obtaining the necessary data for rotation of the $\mathrm{CO}_{2}$ eddy flux. However, analysis of a few periods of high-frequency data indicated that this correction was of the same proportional order of magnitude as for the heat fluxes. Therefore omission of coordinate rotation correction would have only a minor affect on the $\mathrm{CO}_{2}$ fluxes.

[15] $\mathrm{CO}_{2}$ fluxes are often subjected to a variety of additional corrections related to instrumentation and configuration. Corrections are applied for separation of sensors (e.g., distance between the $\mathrm{CO}_{2}$ sample intake and sonic anemometer), tube length and flow in the tube, height of the instrumentation, and frequency loss in the tube and IRGA. The majority of these corrections require analysis of the raw (instantaneous) wind and $\mathrm{CO}_{2}$ data. Although these data were not available with our instrument setup, the following efforts were made to minimize possible errors. For example, the intake of the $\mathrm{CO}_{2}$ sample tube and the krypton hygrometer were located within $15 \mathrm{~cm}$ of the sonic anemometer. The very fast flow down the intake tube ensured turbulent flow in the sample tube, and the relatively short sample line helped to minimize frequency loss within the sample tube. Despite these precautions, we cannot be assured that the fluxes did not have some systematic bias; implications for this are discussed below.

[16] The storage flux $\left(F_{s}\right)$, which accounts for changes in $\mathrm{CO}_{2}$ concentration between the height of the sonic anemometer and the bog surface, was computed from measurements of $\mathrm{CO}_{2}$ concentration at the level of the system intake. Ideally, a concentration profile should be used for this computation, thus the single-level measurement likely underestimated $F_{s}$. However, this discrepancy probably has little bearing on the results reported below because the storage flux is usually $1-3$ orders of magnitude less than the eddy flux, except for a few hours around sunrise and sunset, and for integrations of 1 day or longer $F_{s}$ tends to zero. Net ecosystem exchange, NEE, was then computed as the sum of $F_{e}+F_{s}$. In this paper we use the convention that $F_{e}$ fluxes toward the surface were negative and into the atmosphere were positive, and that $F_{s}$ was positive (negative) if the concentration in the atmosphere increased (decreased). Thus negative NEE indicated an uptake of $\mathrm{CO}_{2}$ by the ecosystem and positive NEE is a loss to the atmosphere.

[17] A variety of environmental measurements were made in support of the flux data. Air temperature and relative humidity (model HMP35 probe, Campbell Scientific, Logan, UT, USA) and wind speed (model 20120, R.M. Young Company, MI, USA) were measured at 0.5 and 2.0 $\mathrm{m}$ from the bog surface. Incoming photosynthetically active radiation (PAR) was measured with a quantum sensor (model QZ190, LI COR, Lincoln, Nebraska, USA). Soil temperatures were measured at depths of $0.01,0.05,0.10$, $0.20,0.40,0.60,0.80,1.5$, and $2.5 \mathrm{~m}$ in one hummock and one hollow with arrays of copper-constantan thermocouples embedded in wood dowels. Depth to the water table was measured in two wells (one in a hollow and one in a hummock) using a float and counterweight system attached to a potentiometer. Frequent manual observations were used 
to verify the water level measurements. Signals from all of the sensors were monitored on the CR7X data logger every $5 \mathrm{~s}$ and averaged every $30 \mathrm{~min}$.

\subsection{Data Handling}

[18] The measurements reported here extend from 1 June 1998 to 31 May 2002. Data retrieved from the data logger underwent several steps of quality assurance and, where necessary, gap filling for missing data. The environmental and meteorological data were plotted as monthly time series and inspected for spurious values, considered as anomalous deviation from normal daily patterns. Such data were rejected. The only significant data gap in the environmental variables occurred when power was lost at the site for 4 days between 28 October and 1 November 1999. The missing data from this period were filled with records from the Environment Canada meteorological station located at the Ottawa International Airport, located $15 \mathrm{~km}$ southwest of the site. Smaller gaps of a few hours were filled by linear interpolation or by the average hourly values computed from the 10 days surrounding the gaps.

[19] The $\mathrm{CO}_{2}$ flux data presented several challenges in terms of data management. Substantial amounts of data were lost due to failures of instrumentation (i.e., the pump breaking down, the IRGA losing power) and to adverse meteorological conditions affecting the sonic anemometer (i.e., heavy rain, freezing rain, or snowfall). Minor data amounts were also lost due to calibration and maintenance of the IRGA and flow system. In addition, eddy flux measurements are highly susceptible to errors during conditions of high thermodynamic stability, which is most prevalent on calm nights. In an earlier paper we examined this problem for the Mer Bleue flux system and determined that measurements below a critical value of friction velocity $\left(u^{*}\right)$ were unreliable [Lafleur et al., 2001a]. Following this earlier procedure, $\mathrm{CO}_{2}$ fluxes were discarded when $u^{*}<0.1 \mathrm{~m} \mathrm{~s}^{-1}$. Finally, monthly time series of the remaining data were filtered in two ways. First, the data were divided into day and night periods and for each data set values beyond \pm 3 standard deviations from the monthly mean were discarded. Second, anomalous nighttime uptake values were discarded. The resulting loss of data from all sources was significant in all years, varying from 33\% (June 1999 to May 2000) to 44\% (June 2000 to May 2001).

\subsection{Gap Filling}

[20] In order to compute seasonal and annual sums of NEE, filling of data gaps was necessary. There is no standard, widely accepted method of gap filling and a variety of methods have been employed [Falge et al., 2001]. In our analysis, any gap less than 2 hours was filled by linear interpolation. For longer gaps, filling techniques were divided into snow-covered and snowfree periods. During snow-covered periods, gaps were filled by weekly mean NEE values. For snow-free periods, we used nonlinear regression to fill nighttime and daytime gaps separately [see Lafleur et al., 2001a]. Nighttime gaps were filled by a relationship between NEE and the $5 \mathrm{~cm}$ hummock soil temperature. Although relationships with other temperatures were investigated, the $5-\mathrm{cm}$ level gave best results. Separate relationships were derived for each of the 4 study years. Daytime gaps were filled by a rectangular parabolic relation between NEE and PAR. As this relation varies in time, due to seasonal changes in plant biomass and microbial activity, separate relationships were derived for each month of the study [e.g., Hollinger et al., 1999; Lafleur et al., 2001a].

[21] Errors for the gap-filled data were assigned on the basis of the accuracy of the models used to fill gaps. The error in the annual accumulated $\mathrm{CO}_{2}$ flux was computed by assigning a fixed error for the measured portion of the record (see below) and model standard errors for the gapfilled portions based on the different models used. Because of these methods, any systematic bias in the measured data would also be present in the gap-filled data.

\subsection{Data Accuracy}

[22] One measure of accuracy of eddy covariance data is the assessment of energy balance closure (i.e., the ratio of the sum of sensible $(H)$ and latent (LE) heat fluxes to the available energy, which is net radiation $\left(R_{n}\right)$ minus soil heat flux $(G)$ ). In this study we regressed daily averages of $H+$ LE on $R_{n}-G$ for each year of observations. The regression slopes varied from 0.89 to 0.91 with intercepts between 1.2 and $6.8 \mathrm{~W} \mathrm{~m}^{-2}$ (which were not significantly different from zero). Coefficients of determination for the 4 years ranged from 0.891 to 0.904 .

[23] Direct assessment of accuracy of $\mathrm{CO}_{2}$ flux data is difficult. Ultimately, it represents the sum of a number of potential errors related to accuracy of the instrumentation and deployment, terrain conditions, and assumptions in flux calculations and corrections. The total error contains both a random (stochastic) and a systematic component. In previous assessments of these errors, researchers typically assign a random measurement error (due to instrumentation and sampling vagaries) of \pm 5 to $\pm 15 \%$ [Goulden et al., 1996; Aubinet et al., 2000]. On the basis that we used similar instrumentation and methods as in previous studies, we have assigned a somewhat conservative random error estimate of $\pm 12 \%$. Without careful consideration, systematic error can be a serious problem. The Mer Bleue site is flat and has good fetch, which in theory should reduce terrain considerations as a source of error. In terms of flux computation, as noted above our data did not include corrections for frequency loss and tube attenuation [Moore, 1986; Suyker and Verma, 1993; Massman, 2000]. Previous studies at sites with short vegetation, such as grassland and tundra, indicate that this correction typically increases the $\mathrm{CO}_{2}$ flux by $10-$ 15\% [Shurpali et al., 1995; Vourlitis and Oechel, 1997; Soegaard and Nordstroem, 1999; A. Suyker, University of Nebraska, personal communication, 2002]. For the Mer Bleue measurement system, we collected a number of short (2 hours) time series of high-frequency data and conducted spectral analysis on these data. A loss of highfrequency cospectra (vertical wind speed and $\mathrm{CO}_{2}$ ) was found. Frequency corrections (stratified by stability and wind speed ranges) were developed from this analysis and computed for one whole growing season. The mean 

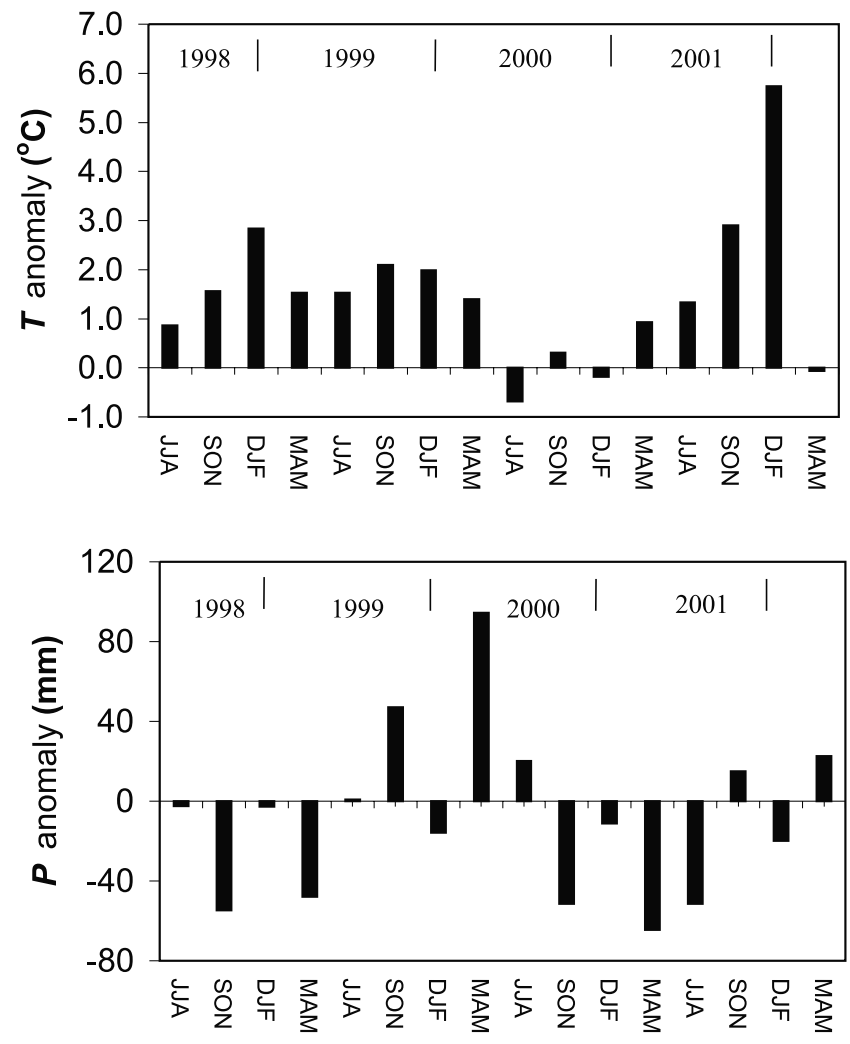

Figure 1. Seasonal temperature $(T)$ and precipitation $(P)$ departures from 30-year (1961-1990) normals. Data from Ottawa International Airport, Meteorological Services of Canada.

correction factor was $1.21 \pm 0.12$ (s.d.). The implications of this analysis are as follows. Although no corrections were applied to the flux data, we recognize the possibility that the values reported here may underestimate the true flux by as much as $20 \%$ on average. However, until we have a more definitive understanding of the frequency response of our system, we are inclined to report the more conservative, uncorrected flux estimates, and we believe that the omission of frequency response corrections does not affect the main findings of this study reported below.

\section{Modeling}

[24] In the latter section of this paper we present a comparison of the measured $\mathrm{CO}_{2}$ exchange with fluxes computed by the PCARS model [Frolking et al., 2002]. This process-oriented ecosystem model simulates the flows and storage of carbon in all the vegetation and soil components of the peatland. Vegetation is separated into nonvascular (moss) and vascular (sedge/grass, shrub, or trees) categories and photosynthesis (PSN) and respiration are computed for each type. These are used to derive net aboveground and belowground production and litterfall. Anaerobic and aerobic decomposition are computed separately, along with production, oxidation, and emission of methane, and dissolved organic carbon production and loss with drainage. Some model parameters are considered as general to all northern peatlands (e.g., PSN and respiration functions for vegetation types), others are site specific (e.g., vegetation type, maximum leaf area index, and biomass). The model is driven by hourly weather (air temperature and PAR), soil temperature, water table, and drainage data. Water table is a key variable as it determines the relative contributions of aerobic and anaerobic decomposition, and influences most vegetation processes. Frolking et al. [2002] initially tested PCARS against the first 2 years of data collected at Mer Bleue. In the present study we examine PCARS performance for the period of June 1998 through December 2001, representing more extreme wet and dry growing seasons, and therefore providing a rigorous test of PCARS sensitivity to water table changes.

\section{Results}

\subsection{Environmental Conditions}

[25] Air temperatures were above normal during most of the study with the exception of the latter half of 2000 (Figure 1a). Growing season (May to September) temperatures for 1998, 1999, and 2001 ranged from $1.7^{\circ}$ to $2.2^{\circ} \mathrm{C}$ above normal, while in 2000 growing season temperature was $0.4^{\circ} \mathrm{C}$ below normal. Precipitation anomalies were more variable (Figure 1b). The most notable anomalies were excess rainfall in the spring and summer of 2000, and a precipitation deficit extending from the fall of 2000 through the summer of 2001. Frostfree period water table depth (WTD) followed these trends (Figure 2). The water table during the wet summer of 2000 was always high, with WTD ranging from -27 to $-45 \mathrm{~cm}$ below the peat hummock surface. Both 1998 and 1999 experienced fluctuating water tables, with maximum depth between -60 and $-70 \mathrm{~cm}$. This limit is likely the normal maximum WTD at this site and may be reached for short periods in any given summer (e.g., DOY 240-248 in 1999). During the dry summer of 2001, the water table dropped below - 70 during July and August, and stayed low for a prolonged dry period which lasted for roughly 5 weeks (DOY 227-262). Total rainfall for July and August of 2001 was $107.7 \mathrm{~mm}$; previous July/August totals of this magnitude or less have occurred 13 times in the past 63 years, on average once in every 5 years.

[26] The snow season at Mer Bleue usually extends from December to March, with peak snow accumulations of between 0.6 and $0.8 \mathrm{~m}$. However, for the period of this study winter conditions varied considerably from year to year (Figure 3). Snow cover during the winter of 19981999 was continuous on the bog from late December (DOY 353 ) to early April (DOY 96) and reached a peak of $0.58 \mathrm{~m}$ in mid-March (DOY 71). The 1999-2000 winter snow cover was discontinuous in time and shallower than the previous year. The first significant accumulation occurred in January 2000, but warm weather caused midwinter melts and delayed a significant snow cover. Peak snow depth reached $0.44 \mathrm{~m}$ in late February. By early March, snow was gone from the bog except for a brief accumulation at the beginning of April. A late lasting snowpack occurred during the 2000-2001 winter. Snow did not begin to accumulate 


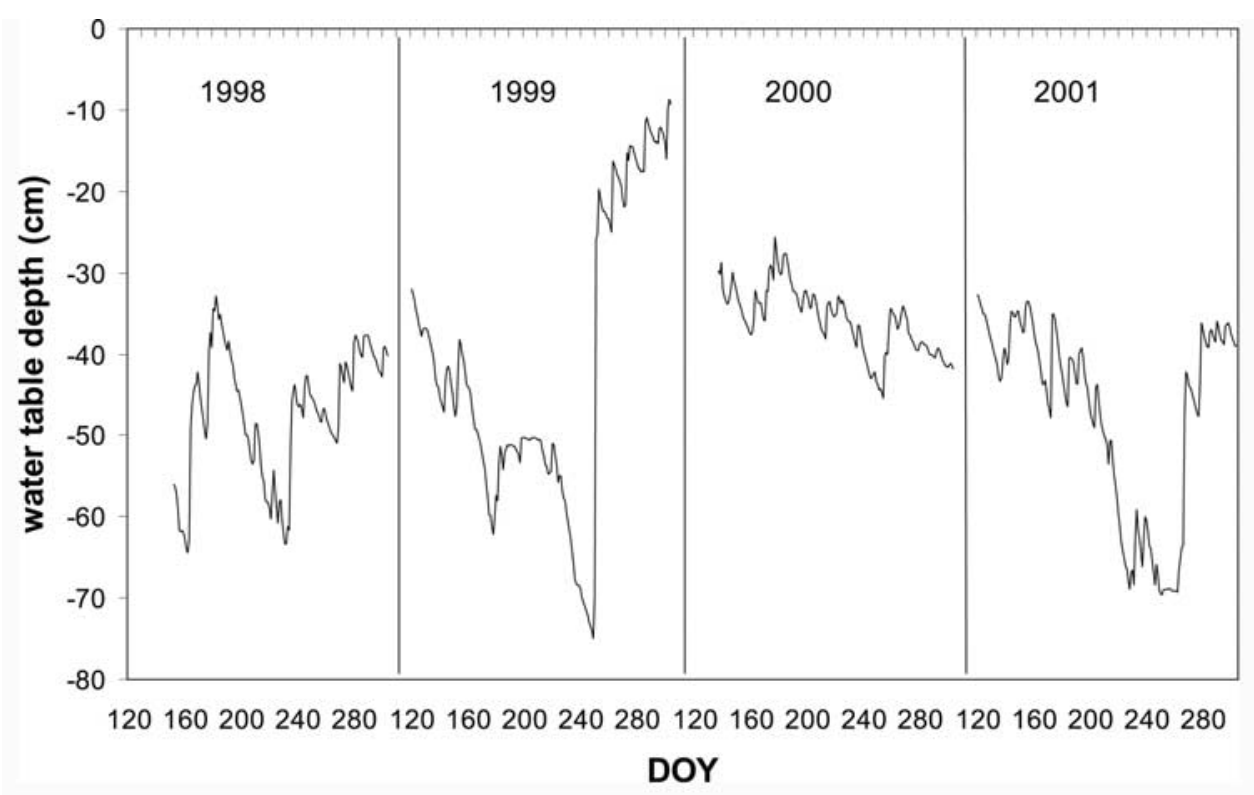

Figure 2. Water table depth below mean hummock surface.

on the bog until early January, but in this winter the pack continued to build, reaching peak depth $(0.58 \mathrm{~cm})$ in late March and complete ablation did not occur until mid-April (DOY 101). In 2001-2002 an early snow cover developed, but melt thinned it in early March.

\subsection{Growing Season Carbon Dioxide Fluxes}

[27] The cyclic pattern of $\mathrm{CO}_{2}$ fluxes (summertime uptake and winter loss) over the 4 years of the study indicates that maximum summer uptake was near -0.45 $\mathrm{mg} \mathrm{CO} \mathrm{m}^{-2} \mathrm{~s}^{-1}$ and that summer nighttime respiration was typically near $0.2 \mathrm{mg} \mathrm{CO} \mathrm{Cm}^{-2} \mathrm{~s}^{-1}$, but larger values were sometimes recorded (Figure 4). Fluxes in winter were consistently smaller than during the summer, with losses typically between 0.05 and $0.1 \mathrm{mg} \mathrm{CO} \mathrm{m}^{-2} \mathrm{~s}^{-1}$. Peak uptake occurred in late June and early July of each year. Of particular note was the variation in pattern of the summer $\mathrm{CO}_{2}$ sink (i.e., the increase in NEE sink in spring, peaking in summer, and decline of NEE in fall). For example, the wet, cool summer (2000) displayed a symmetrical pattern of NEE about the summer peak. However, in 2001, the year with the latest winter snow cover and the longest summer drought, was less symmetrical, with a steep increase in $\mathrm{CO}_{2}$ sink in spring, an earlier peak uptake, and a gentler decline in NEE in late summer and fall than in other years.

[28] Mean daily NEE fluxes for the summer, June to September, were similar in the first 3 years of the study $\left(-2.30\right.$ to $\left.-2.84 \mathrm{~g} \mathrm{CO}_{2} \mathrm{~m}^{-2} \mathrm{~d}^{-1}\right)$, but were significantly reduced to $-1.56 \mathrm{~g} \mathrm{CO}_{2} \mathrm{~m}^{-2} \mathrm{~d}^{-1}$ in 2001 (Table 1). Maximum daily uptake ranged between -7.6 and $-6.8 \mathrm{~g}$ $\mathrm{CO}_{2} \mathrm{~m}^{-2} \mathrm{~d}^{-1}$. Although most days were net sinks for $\mathrm{CO}_{2}$ during the growing season, substantial daily losses up to 4.0 $\mathrm{g} \mathrm{CO}_{2} \mathrm{~m}^{-2} \mathrm{~d}^{-1}$ occurred in all four growing seasons and were associated with cool and heavily overcast days. The accumulated $\mathrm{CO}_{2}$ sink for the 4-month period varied from a maximum of $-346 \mathrm{~g} \mathrm{CO}_{2} \mathrm{~m}^{-2}$ in 1998 to a minimum of $-191 \mathrm{~g} \mathrm{CO}_{2} \mathrm{~m}^{-2}$ in 2001 (Table 2).

[29] The contrasting water table conditions during the 2000 and 2001 summers (Figure 2) greatly altered the $\mathrm{CO}_{2}$ exchange. Average diurnal trends for each summer month showed that during the wet year (2000) mean daily NEE was greatest in July and only slightly smaller in June and August (Figure 5a). Although NEE was reduced in September 2000, the bog was still a daily sink for $\mathrm{CO}_{2}$. The largest mean daily NEE in 2001 occurred in the month of June (Figure 5b). While water table decreased dramatically during July and August, daily NEE sink was halved in July, reached a zero balance in August, even-

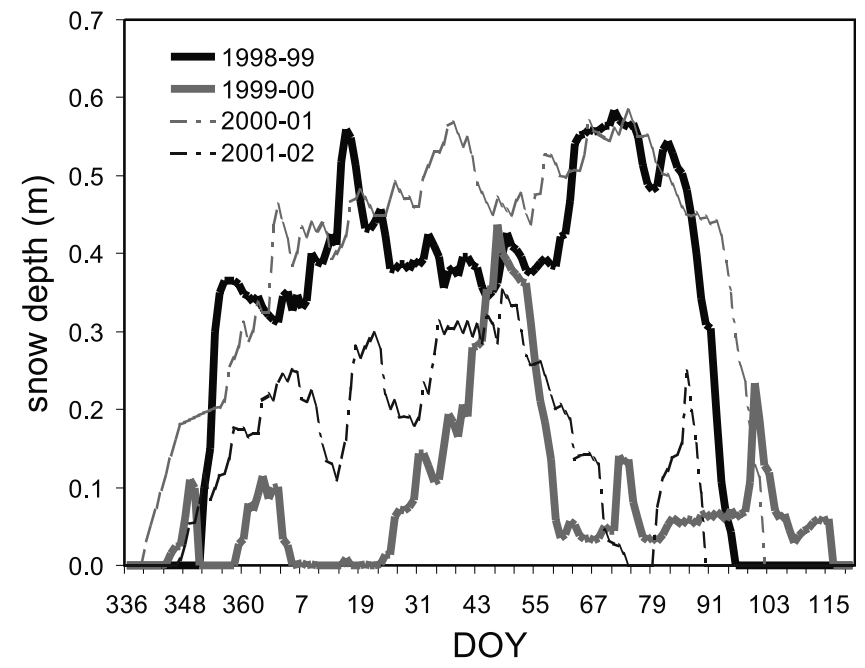

Figure 3. Trends in mean snow depth at Mer Bleue measured near the instrument tower. 


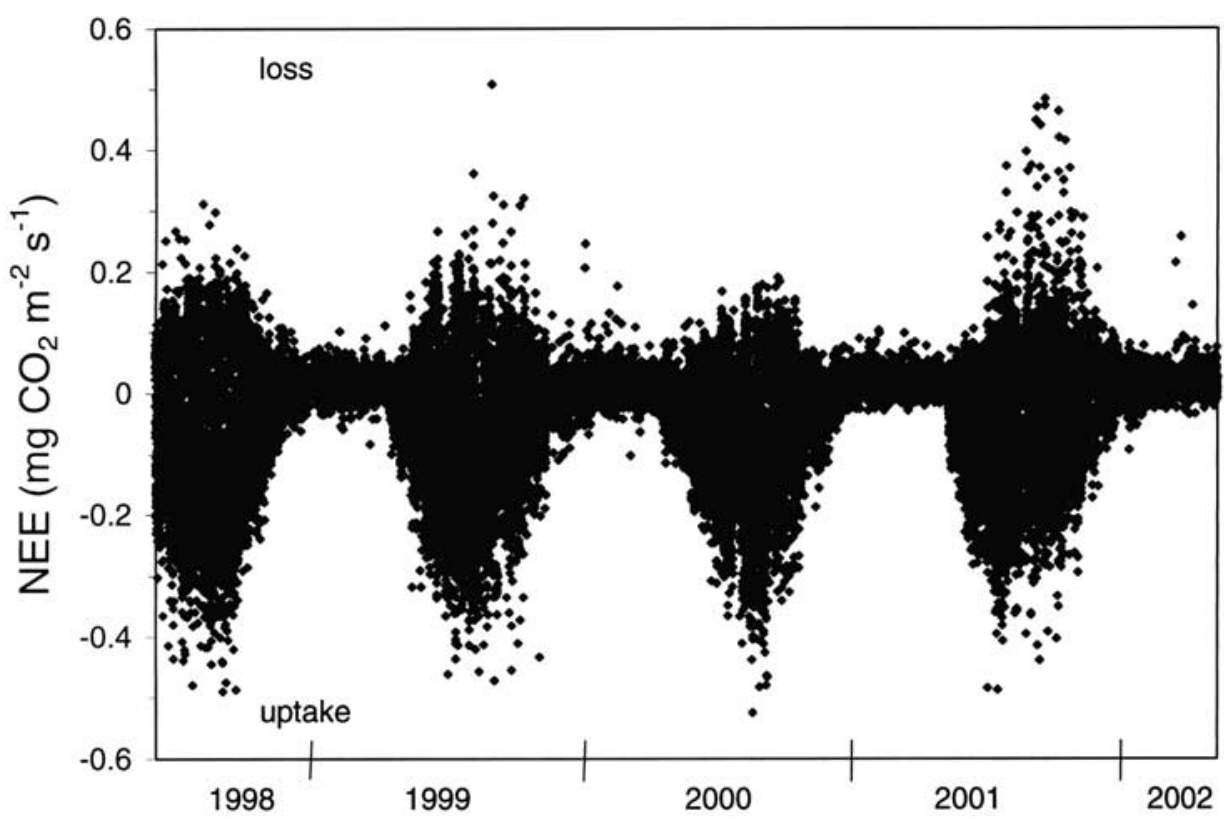

Figure 4. Annual trends of net ecosystem $\mathrm{CO}_{2}$ exchange (NEE) at Mer Bleue. Points are 30-min averages and include measured data after filtering (see text).

tually became net daily loss of $\mathrm{CO}_{2}$ in September 2001 . Mean nighttime fluxes (i.e., respiration losses) were greater in all months during the dry summer (2001) compared to the wet year (2000). Monthly mean daytime uptake decreased steadily during 2001, compared to the strong $\mathrm{CO}_{2}$ uptake in July and August of 2000 (Figure 6). Thus it appears that both PSN and respiration were affected in this comparison. Although we have no direct measurement of PSN, nighttime NEE is taken to be a direct measurement of ER. Analyses of mean monthly nighttime NEE for all years of the study showed that mean nighttime NEE in the 2001 summer was generally similar to that of 1998 and 1999, and that the 2000 means were generally smaller (Table 3 ). Therefore the main response was a reduction in ER in the wet year, as opposed to increased respiration in the dry year. This

Table 1. Mean, Maximum, and Minimum Daily NEE Fluxes in Summer (June to September) and Winter (December to March) ${ }^{\mathrm{a}}$

\begin{tabular}{lcccc}
\hline \hline \multicolumn{1}{c}{ Summer } & 1998 & 1999 & 2000 & 2001 \\
\hline Mean (s.d.) & $-2.84^{\mathrm{b}}$ & $-2.30^{\mathrm{b}}$ & $-2.62^{\mathrm{b}}$ & $-1.56^{\mathrm{c}}$ \\
& $(2.72)$ & $(2.45)$ & $(2.41)$ & $(2.45)$ \\
Maximum uptake & -7.64 & -7.28 & -6.83 & -6.77 \\
Maximum loss & 3.92 & 3.59 & 2.96 & 2.67 \\
\hline Winter & $1998-1999$ & $1999-2000$ & $2000-2001$ & $2001-2002$ \\
\hline Mean (s.d.) & $0.98^{\mathrm{b}}$ & $0.74^{\mathrm{c}}$ & $1.09^{\mathrm{d}}$ & $1.05^{\mathrm{b}, \mathrm{d}}$ \\
& $(0.47)$ & $(0.32)$ & $(0.23)$ & $(0.25)$ \\
Maximum & 2.10 & 1.44 & 1.58 & 1.58 \\
\hline \hline
\end{tabular}

avalues are in $\mathrm{g} \mathrm{CO}_{2} \mathrm{~m}^{-2} \mathrm{~d}^{-1}$. Negative sign indicates net uptake and positive sign indicates net loss. s.d. is standard deviation. Mean values within rows having the same letter are not statistically different $(P>0.05)$, as determined by analysis of variance and Tukey's post hoc difference of means test for unequal $n$. finding is also supported by the reduced nighttime NEE in August and September of 1999 when a brief drought developed (Figure 2).

\subsection{Winter Carbon Dioxide Fluxes}

[30] There was a small but persistent wintertime $\mathrm{CO}_{2}$ flux in all years (Figure 4); mean daily winter fluxes ranging from 0.74 to $1.09 \mathrm{~g} \mathrm{CO}_{2} \mathrm{~m}^{-2} \mathrm{~d}^{-1}$ (Table 1). The seasonal trend in weekly average $\mathrm{CO}_{2}$ fluxes during 1998-1999, 2000-2001, and 2001-2002 showed considerable variability with a tendency to slightly larger fluxes toward the end of winter (Figure 7a). In contrast, fluxes during the 1999-2000 winter declined in magnitude as the winter progressed, resulting in significantly smaller average fluxes compared to the other winters (Table 1). We believe this difference can be attributed to excessive cooling and subsequent freezing of the peat soil, which

Table 2. Summary of Seasonal and Annual NEE by Year $^{\mathrm{a}}$

\begin{tabular}{lcccc}
\hline \multicolumn{1}{c}{ Period } & $1998-1999$ & $1999-2000$ & $2000-2001$ & $2001-2002$ \\
\hline Spring & -70 & -72 & -96 & -24 \\
Summer & -346 & -282 & -321 & -191 \\
Fall & 19 & 11 & 32 & 51 \\
Winter & 119 & 89 & 132 & 127 \\
& & & & -37 \\
Annual & -278 & -254 & -251 & $( \pm 123)$ \\
(Error) & $( \pm 49)$ & $( \pm 150)$ & $( \pm 2)$ & $( \pm 49)$ \\
$\mathrm{g} \mathrm{C} \mathrm{m}^{-2} \mathrm{yr}^{-1}$ & $-76 \pm 13$ & $-69 \pm 41$ & $-68 \pm 34$ & $-10 \pm 13$ \\
\hline
\end{tabular}

${ }^{a}$ Annual period is from 1 June to 31 May. Seasonal periods are spring (April-May), summer (June-September), Fall (October-November), and Winter (December-March). All values are accumulated NEE in $\mathrm{g} \mathrm{CO}_{2}$ $\mathrm{m}^{-2}$ period ${ }^{-1}$ unless otherwise stated; negative indicates uptake by the ecosystem (loss from the atmosphere). 

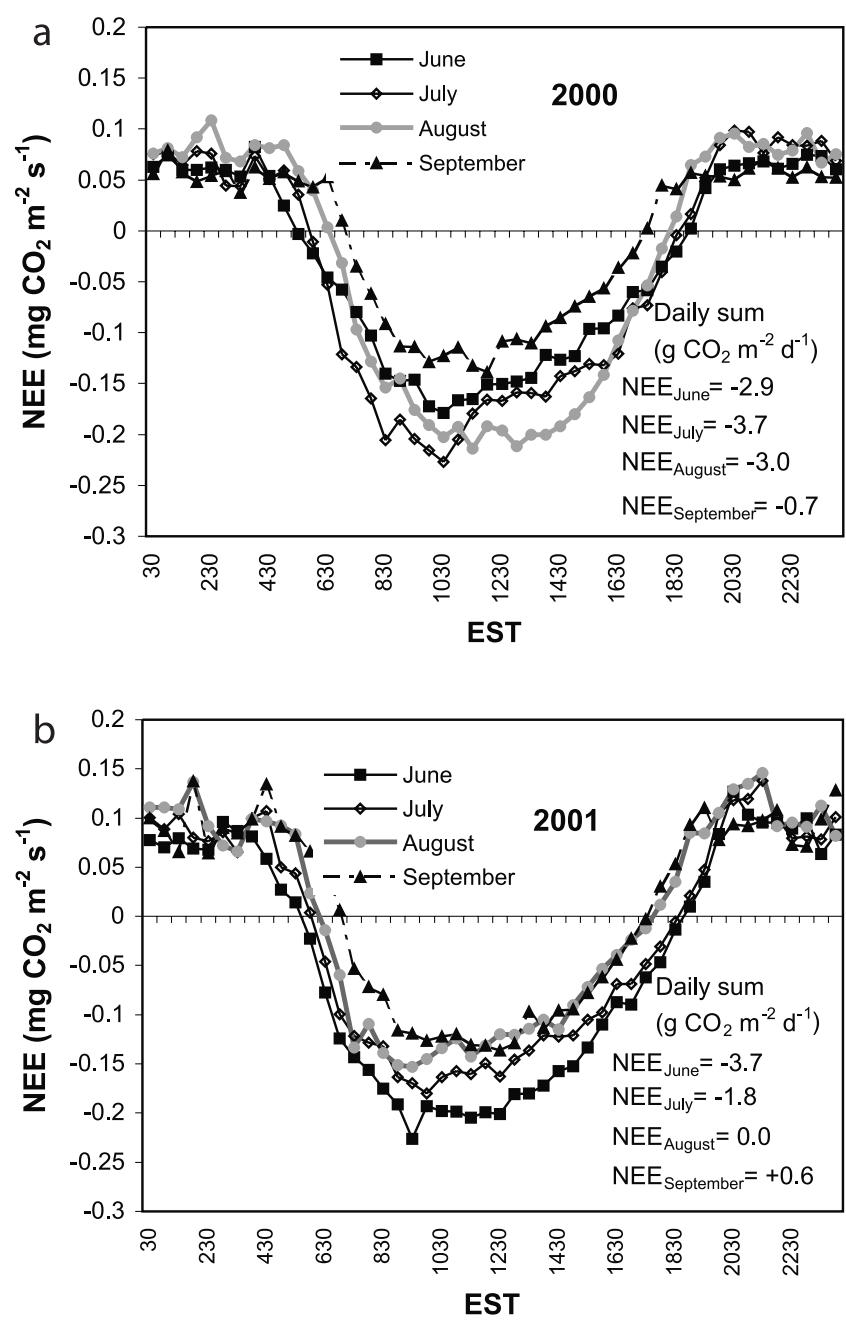

Figure 5. Mean monthly diurnal course of NEE for summer months in (a) 2000 and (b) 2001. Each point is the monthly mean of measured data points for that half hour.

was directly related to differences in snow accumulation. Although soil temperatures in the peat hollows rarely fell below freezing, temperature in some portion of the peat hummocks was usually below freezing in winter. Snow cover controlled the degree of freezing and depth to which freezing occurred. Ultimately, this influenced decomposition and $\mathrm{CO}_{2}$ exchange. For example, the lowest total $\mathrm{CO}_{2}$ loss and mean daily flux occurred in 19992000 , the winter with a discontinuous snow cover (Figure 3). During this winter, mean January temperature at $5 \mathrm{~cm}$ depth in the peat hummocks cooled to $-5^{\circ} \mathrm{C}$, at least $3^{\circ} \mathrm{C}$ colder than in any other winter. As a result, the frost line penetrated well below the $20 \mathrm{~cm}$ depth in the hummocks in January and February (Figures $7 \mathrm{~b}$ and $7 \mathrm{c}$ ). Although not shown, 1999-2000 was the only winter when subzero monthly mean temperatures were recorded at the $5 \mathrm{~cm}$ depth in the peat hollows. In other words, during the midwinter of 1999-2000 most of the aerobic zone of the peatland was frozen to some extent and this probably reduced decomposition. It should also be noted that because of the early snowmelt, the hummock tops

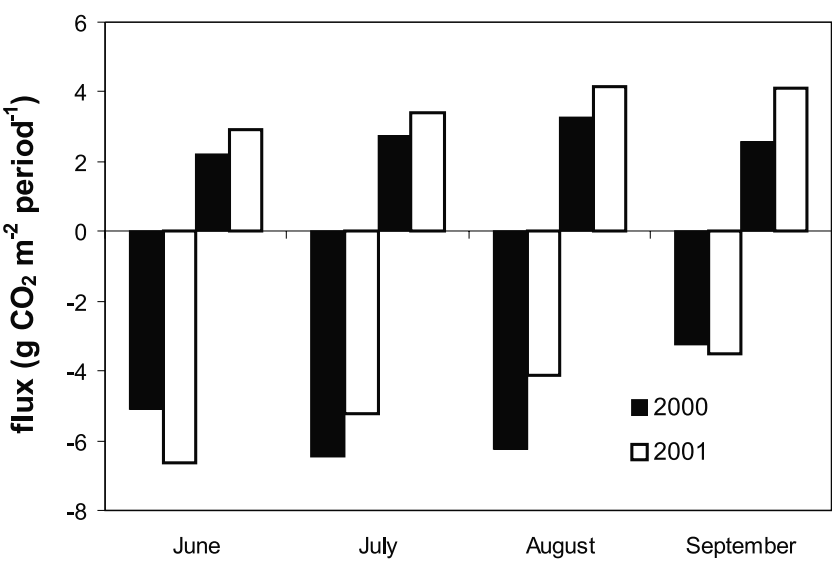

Figure 6. Nighttime (positive) and daytime (negative) mean monthly $\mathrm{CO}_{2}$ fluxes for 2000 (solid bars) and 2001 (open bars).

were snow free for most of the month of March 2000. In the last 2 weeks of March some daytime $\mathrm{CO}_{2}$ uptake was recorded, presumably indicating PSN by the mosses, which reduced average NEE fluxes at the end of March (Figure 7a).

[31] During the winters of 1998-1999, 2000-2001, and 2001-2002 a continuous snowpack was established early in the winter and persisted until the main melt occurred in late March or early April. Soil temperatures were considerably warmer during these winters, averaging only $-1^{\circ}$ to $-2^{\circ} \mathrm{C}$ in the upper portion of the hummocks and near $0^{\circ} \mathrm{C}$ at the $20-\mathrm{cm}$ level. Presumably, the amount of ground ice present during these winters would have been substantially less than in 1999-2000. Mean daily $\mathrm{CO}_{2}$ fluxes were statistically similar during the three snowy winters (Figure 7 and Table 1).

[32] Average air temperatures showed no relationship with winter $\mathrm{CO}_{2}$ losses. The 1999-2000 winter was not the coldest winter, averaging $2.0^{\circ} \mathrm{C}$ above normal (Figure 1). The 1998-1999 and 2001-2002 winter temperatures were also above normal, while the 2000-2001 winter was the coldest at $0.2^{\circ} \mathrm{C}$ below normal. All winter months in each of the 4 years experienced subfreezing air temperatures. The bog represents a huge thermal mass, with approximately $5 \mathrm{~m}$ of saturated peat soil and a mean annual

Table 3. Comparison of Monthly Summer Nighttime $(\mathrm{PAR}=0)$ NEE Fluxes ${ }^{\mathrm{a}}$

\begin{tabular}{lccrr}
\hline Month & 1998 & 1999 & 2000 & 2001 \\
\hline June & $0.077^{\mathrm{b}, \mathrm{c}}$ & $0.104^{\mathrm{d}}$ & $0.064^{\mathrm{b}}$ & $0.083^{\mathrm{c}}$ \\
& $(0.002)$ & $(0.005)$ & $(0.002)$ & $(0.004)$ \\
July & $0.111^{\mathrm{b}}$ & $0.131^{\mathrm{c}}$ & $0.076^{\mathrm{d}}$ & $0.098^{\mathrm{e}}$ \\
& $(0.003)$ & $(0.003)$ & $(0.003)$ & $(0.004)$ \\
August & $0.125^{\mathrm{b}}$ & $0.080^{\mathrm{c}}$ & $0.081^{\mathrm{c}}$ & $0.104^{\mathrm{d}}$ \\
& $(0.005)$ & $(0.005)$ & $(0.003)$ & $(0.004)$ \\
September & $0.100^{\mathrm{b}}$ & $0.068^{\mathrm{c}}$ & $0.057^{\mathrm{c}}$ & $0.097^{\mathrm{b}}$ \\
& $(0.002)$ & $(0.002)$ & $(0.002)$ & $(0.005)$ \\
\hline
\end{tabular}

${ }^{\text {a }}$ Values are monthly means, with standard errors in parenthesis. Units are in $\mathrm{mg} \mathrm{CO}_{2} \mathrm{~m}^{-2} \mathrm{~s}^{-1}$. Means within rows having the same letter are not statistically different $(P>0.05)$. 

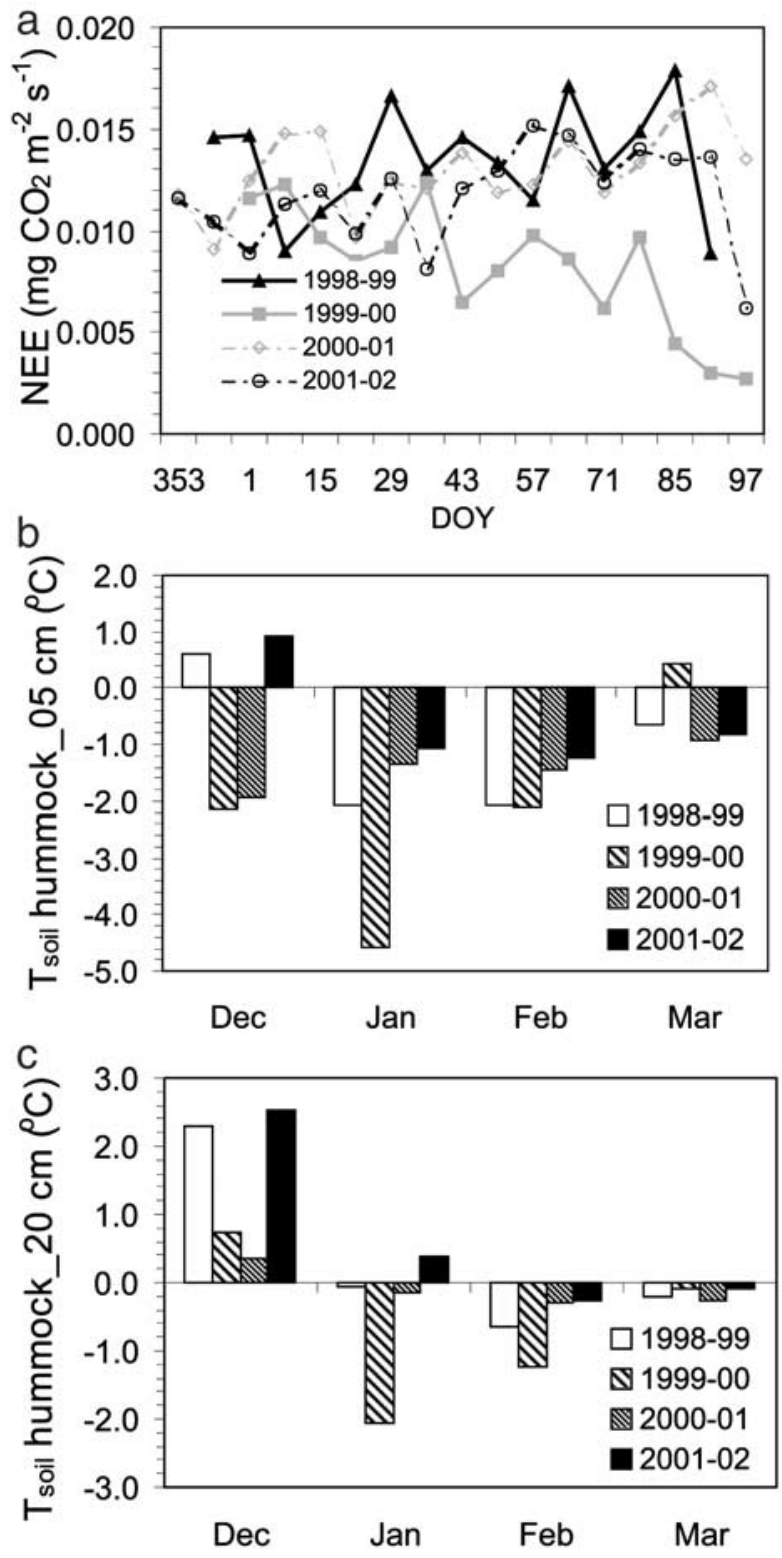

Figure 7. (a) Weekly mean NEE for the winter period (1 December to 31 March) by year; (b) monthly mean hummock 5-cm depth soil temperatures; and (c) monthly mean hummock 20 -cm depth soil temperatures.

temperature at $2.5 \mathrm{~m}$ of $7.0^{\circ} \mathrm{C}$ (annual range $5.75^{\circ}-$ $8.05^{\circ} \mathrm{C}$ ). Thus any appreciable snow cover decouples the soil from the atmosphere, allowing the thermal reservoir to warm the upper soils, which in turn promotes decomposition. In order to reduce winter $\mathrm{CO}_{2}$ losses, a period of subfreezing air temperatures with little or no snow cover is required.

\subsection{Annual Carbon Accumulation}

[33] Annual NEE was similar during the first 3 years of measurements, varying from a sink of $-278( \pm 49)$ in 1998 1999 to $-251( \pm 123) \mathrm{g} \mathrm{CO}_{2} \mathrm{~m}^{-2}$ (Table 2). In the dry year (2001-2002), however, the bog was a much smaller $\mathrm{CO}_{2}$ sink, $-34( \pm 49) \mathrm{g} \mathrm{CO}_{2} \mathrm{~m}^{-2}$. Despite the similarity of the annual NEE in the first 3 years, there were marked variations in seasonal NEE between years, as illustrated by the time series of the accumulated daily NEE (Figure 8). Although early summer sequestering of $\mathrm{CO}_{2}$ (shown by the slope of accumulated NEE versus time) was not greatly different between years, the annual sink strength of the peatland was affected by three other features: (1) the timing of the fall slow down in NEE accumulation and subsequent switch from a $\mathrm{CO}_{2}$ sink to a source, (2) the accumulated loss of $\mathrm{CO}_{2}$ over the winter, and (3) the date of onset and rate of carbon accumulation in spring (i.e., switch from a source to a sink). These seasonal differences in $\mathrm{CO}_{2}$ flux reflect the bog's overall response to climate variations.

[34] During the nondrought years (1998 and 2000) strong daily $\mathrm{CO}_{2}$ uptake was recorded well into the fall with the point of zero NEE balance (i.e., switch from a net accumulating to a net losing system) reached on DOY 274 in 2000 to DOY 286 in 1998. Daily NEE declined earlier in 1999, possibly a result of the deep draw down of the water table in August (Figure 2), with modest uptake continuing until a zero balance on about DOY 294. In contrast, during the dry year (2001) the growing season $\mathrm{CO}_{2}$ uptake began to decline after DOY 203, with very little net uptake of $\mathrm{CO}_{2}$ thereafter. The zero balance was reached on DOY 249, some 30-40 days earlier than in the previous years and 18 days before the end of the drought period. These results suggest that the bog vegetation, particularly the mosses, did not recover after the period of drought ended. This is consistent with results from studies at other peatlands stressed by water deficits [Alm et al., 1999; Griffis et al., 2000].

[35] The slope of accumulated NEE versus time was similar $\left(0.96-1.08 \mathrm{~g} \mathrm{CO}_{2} \mathrm{~m}^{-2} \mathrm{~d}^{-1}\right)$ for the 3 years with continuous snow covers, 1998-1999, 2000-2001, and 2001-2002. Thus total $\mathrm{CO}_{2}$ losses during the December to March period were similar, $119-132 \mathrm{~g} \mathrm{~m}^{-2}$ (Table 2).

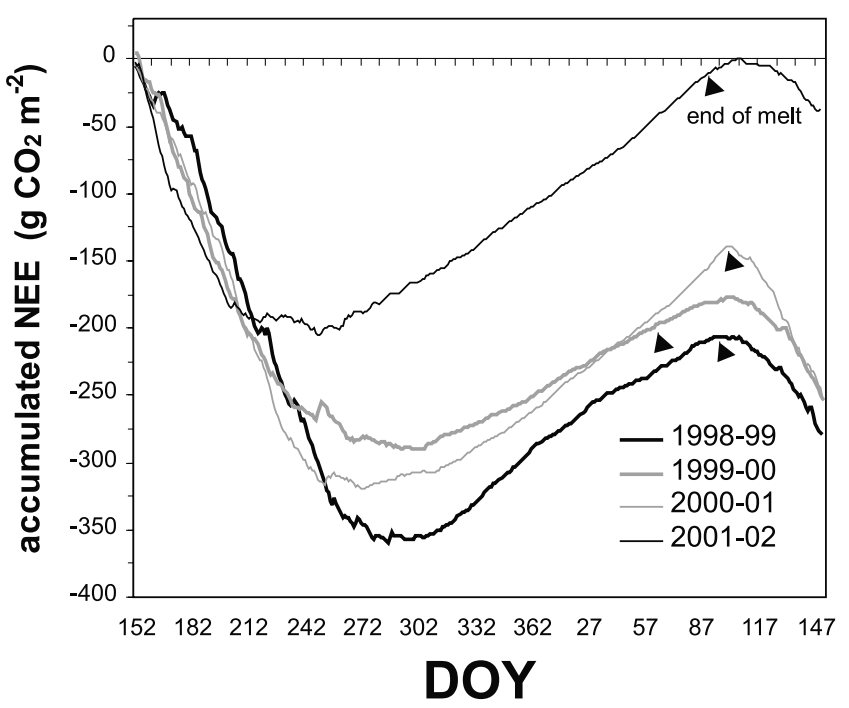

Figure 8. Accumulated NEE for the period 1 June to 31 May by year. Negative is a net ecosystem uptake of $\mathrm{CO}_{2}$ and positive is a net loss. 
Table 4. Comparison of Monthly Spring $\mathrm{CO}_{2}$ Flux and Meteor$\operatorname{ology}^{\mathrm{a}}$

\begin{tabular}{clrr}
\hline Meteorology & Month & 2001 & 2002 \\
\hline$\sum \mathrm{NEE}, \mathrm{g} \mathrm{CO}_{2} \mathrm{~m}^{-2}$ & April & -9.5 & 5.9 \\
& May & -86.5 & -29.8 \\
Air temperature, deg & April & 6.1 & 6.1 \\
& May & 13.9 & 10.9 \\
Soil temperature, deg & April & 3.8 & 4.4 \\
& May & 13.6 & 10.8 \\
PAR, $\mu \mathrm{mol} \mathrm{m}^{-2} \mathrm{~s}^{-1}$ & April & 419 & 323 \\
& May & 383 & 360 \\
Hours with PAR $>1000$ & April & 276 & 194 \\
& May & 242 & 205 \\
\hline
\end{tabular}

${ }^{\mathrm{a}}$ Negative $\mathrm{CO}_{2}$ flux indicates uptake, positive indicates net loss. Temperatures and PAR are mean daily values for the month.

The rate of $\mathrm{CO}_{2}$ loss was noticeably less (slope $=-0.77 \mathrm{~g}$ $\mathrm{CO}_{2} \mathrm{~m}^{-2} \mathrm{~d}^{-1}$ ) during the 1999-2000 winter, when snow cover was discontinuous, with the coldest soil temperatures and deepest soil freezing recorded. As a result accumulated $\mathrm{CO}_{2}$ loss for the 1999-2000 winter was significantly smaller $\left(89 \mathrm{~g} \mathrm{~m}^{-2}\right)$ than for the other 3 years.

[36] The timing and rate of $\mathrm{CO}_{2}$ sequestration in the spring period varied considerably between years (Figure 8 and Table 4). Hummock moss species begin to fix $\mathrm{CO}_{2}$ almost immediately after snowmelt [Bubier et al., 1998]. In all years, we measured small net daytime uptakes within a few days of the end of snowmelt suggesting PSN by the moss cover was taking place. Interannual differences in spring $\mathrm{CO}_{2}$ fluxes are likely related to the phenology of the vascular plant cover on the bog and the environmental conditions that influence phenology (i.e., temperature and light). We do not have comprehensive phenology data, but a comparison of carbon fluxes for spring 2001 and 2002 indicate that differences in daily NEE were mostly due to greater daytime uptake of $\mathrm{CO}_{2}$ (i.e., PSN) than to differences in nighttime (i.e., respiration) losses (Figure 9). Even though snowmelt was 1 week earlier in 2002, April hummock soil temperatures were on average $0.6^{\circ} \mathrm{C}$ cooler and mean daily PAR flux was almost one-third less in 2002 than in 2001 (Table 4). May 2002 was also cooler and cloudier, resulting in substantially less $\mathrm{CO}_{2}$ uptake than in May 2001. There were 23\% fewer hours with PAR > 1000 in 2002 than in 2001 (Table 4), an indication of reduced time when the vascular plants at Mer Bleue would be photosynthesizing at their maximum rate [Bubier et al., 2003].

\subsection{Modeling of Carbon Fluxes}

[37] Time series of ecosystem $\mathrm{C}$ exchange predicted by PCARS and measured by the flux tower were compared from 1 June 1998 to 31 December 2001. The model predicts shrub PSN and respiration, moss PSN and respiration, and heterotrophic respiration as independent variables derived from the various plant and soil processes, driven by weather variables; total PSN, total ER, and NEE are calculated as sums. The tower directly measures NEE and PSN and ER were derived from tower data as follows. During the growing season, nighttime tower NEE was taken to be measured ER and daytime ER was predicted from $\mathrm{NEE}_{\text {nighttime }}$ versus soil temperature relationships; separate relationships were developed for each year. PSN was then obtained by subtracting daytime ER from daytime NEE.
[38] PCARS consistently overestimated tower-derived ER and, in all growing seasons except 1998, PSN (Figure 10a). Modeled and tower-derived daily ER and PSN were highly correlated $\left(r^{2}=0.87\right.$ and 0.86 , respectively, Table 5). Simulated ER was approximately $45 \%$ higher than measured for June 1998 to December 2001, and about 70\% higher for June 1999 to December 2001; simulated PSN was approximately $15 \%$ higher than measured for June 1998 to December 2001, and 30\% higher for June 1999 to December 2001 (Table 5). Some of this bias may be due to tower underestimation of $\mathrm{CO}_{2}$ fluxes (see section 3.4 above); some may be due to misparameterization of model functions (e.g., temperature sensitivity of decomposition rates); and some to misrepresentation of some process (e.g., first-order decline in decomposition rate with mass loss, see Frolking et al. [2001]). However, the patterns of model and tower-derived ER tracked well in both years, with both trends showing lower ER during the wet summer of 2000 (Figure 10a). Simulated and measured PSN also had very similar patterns, particularly in the wetter growing seasons of 1998 and 2000 (Figure 10a). However, simulated PSN was greater in wetter summers than the drier summers, while tower-derived PSN was lowest in the wettest summer (2000). Manual chamber $\mathrm{CO}_{2}$ flux measurements made during the 2000 and 2001 growing seasons also showed higher ER in the drier summer (2001) and similar rates of
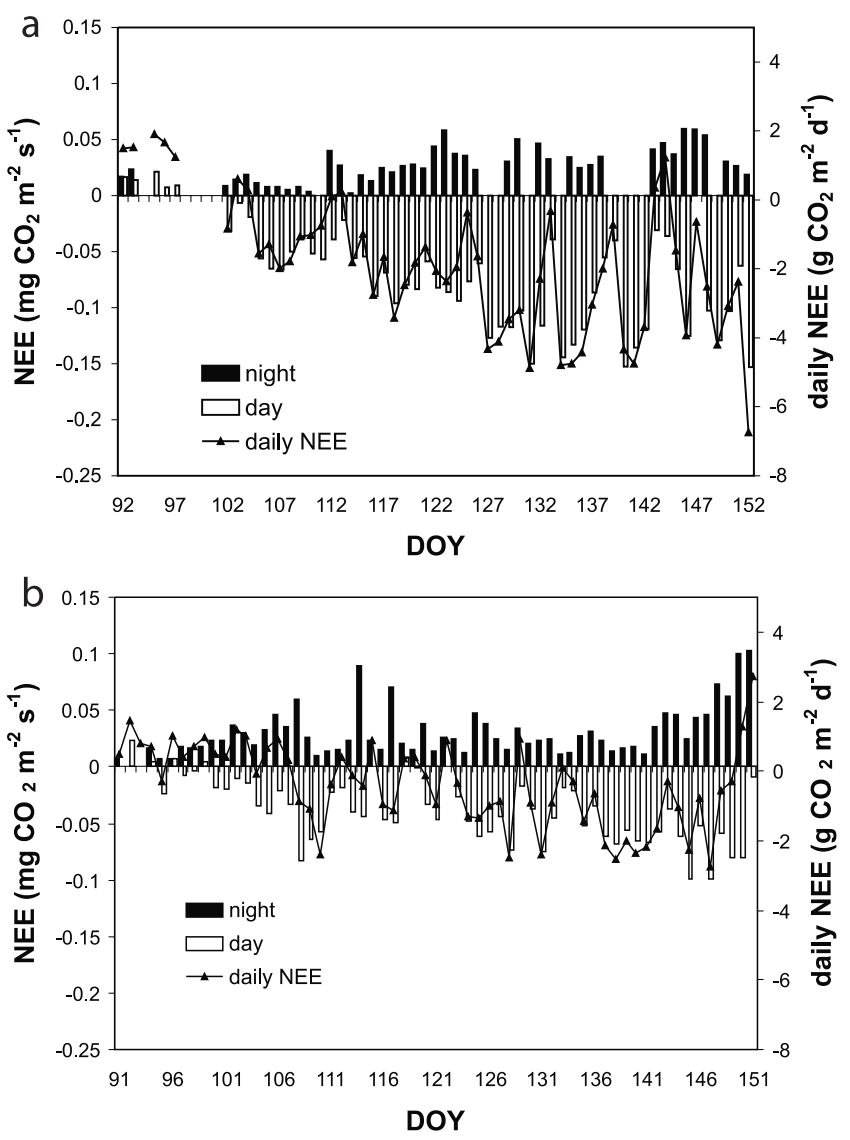

Figure 9. Mean 30-min nighttime (solid bars) and daytime (open bars) $\mathrm{CO}_{2}$ flux and daily NEE (triangles) for spring, 1 April to 31 May, of (a) 2000 and (b) 2001. 


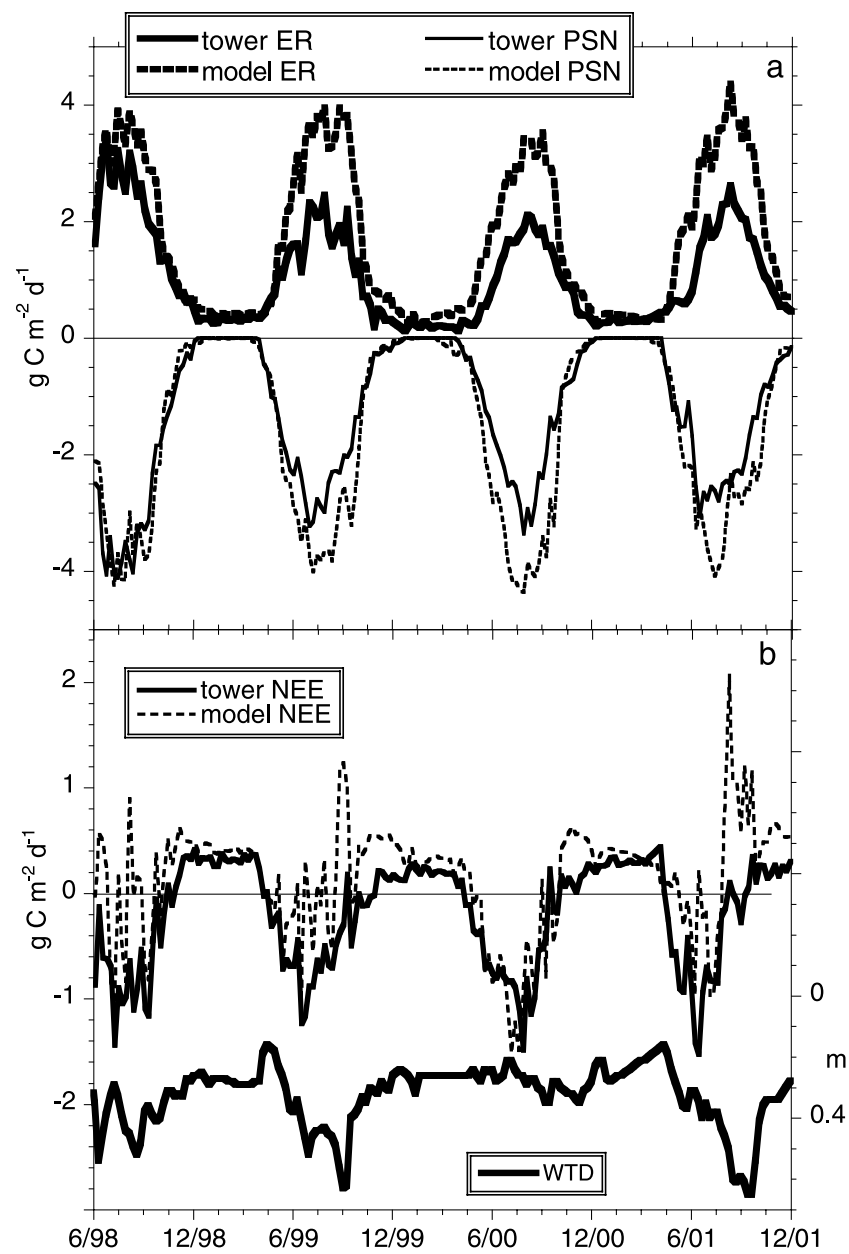

Figure 10. (a) Simulated (dashed lines) and observed (solid lines) weekly mean total photosynthesis (PSN $\leq 0$ ) and total ER $(E R \geq 0)$ for June 1998 through December 2001. (b) Simulated (dashed line) and observed (solid line) weekly mean net ecosystem exchange of $\mathrm{CO}_{2}$ (NEE), and observed weekly mean water table depth (thick solid line and right axis). Simulations with PCARS included evergreen shrub and moss vegetation only.

PSN until late in the dry summer, when PSN declined significantly [Bubier et al., 2003]. Since the model overestimated ER more than PSN, simulated NEE was biased toward respiration; it was also less correlated with observed NEE (Table 5 and Figure 10b). Simulated NEE during periods of low water table was much more positive (net $\mathrm{CO}_{2}$ loss to the atmosphere) than observed by the tower;
Table 6. Comparison of PCARS and Tower Accumulated NEE Fluxes $^{\mathrm{a}}$

\begin{tabular}{|c|c|c|c|c|c|c|c|c|c|}
\hline & \multicolumn{3}{|c|}{ ER } & \multicolumn{3}{|c|}{ PSN } & \multicolumn{3}{|c|}{ NEE } \\
\hline & 1999 & 2000 & 2001 & 1999 & 2000 & 2001 & 1999 & 2000 & 2001 \\
\hline \multicolumn{10}{|c|}{ Growing Period } \\
\hline PCARS & 469 & 390 & 466 & -465 & -493 & -450 & 5 & -101 & 17 \\
\hline Tower & 292 & 215 & 252 & -383 & -320 & -327 & -92 & -104 & -76 \\
\hline \multicolumn{10}{|c|}{ Annual } \\
\hline PCARS & 593 & 508 & 611 & -512 & -533 & -518 & 81 & -26 & 93 \\
\hline Tower & 368 & 287 & 353 & -430 & -360 & -381 & -63 & -73 & -28 \\
\hline
\end{tabular}

${ }^{\mathrm{a}}$ Growing period is from May to September inclusive; annual is calendar year. ER is ecosystem respiration, PSN is photosynthesis, and NEE is net ecosystem exchange. All fluxes are in $\mathrm{g} \mathrm{C} \mathrm{m}^{-2}$ period $^{-1}$.

this was most noticeable during the extended dry period in the late summer of 2001 and could be due to an overestimation of decomposition, an overestimation of plant respiration, and/or and underestimation of PSN. Overall, simulated and observed PSN, ER, and NEE varied in the same manner for wet and dry years, but, particularly for NEE, the model was much more variable than observations (Table 6).

[39] In the PCARS simulations, decomposition contributed slightly more than half of total ER; it was the dominant source of $\mathrm{CO}_{2}$ during the fall, winter, and early spring, but was less than autotrophic or plant respiration during the growing season, except during the very dry period in 2001 (Figure 11). Shrubs dominated over mosses in plant carbon exchange, accounting for about $90 \%$ of respiration, $80-85 \%$ of $\mathrm{PSN}$, and $70-75 \%$ of net primary production (NPP). In all but the wet summer of 2000, moss NPP had early and late summer peaks, was near zero during the dry midsummer period. Each year, moss NPP was greater than shrub NPP only during April and November. Shrub NPP responded to drought only when the water table was quite deep in 2001, and this response was primarily a reduction in PSN due to a low water table causing plant water stress.

[40] One other point of note is the comparison of PCARS and tower fluxes during the spring period. In 2000, the PCARS-tower differences in PSN and ER were small in spring and increase toward the end of the growing season (Figure 10a). During 2001 these differences, particularly ER, were large in early spring and only increased slightly during the growing season. Snowmelt was very late in the 2001 spring and a $\mathrm{CO}_{2}$ sink developed very rapidly following melt (Figure 8). In 2000, the melt was very early, but the change over from a $\mathrm{CO}_{2}$ sink to a source did not take place

Table 5. Linear Correlations Between Simulated and Measured Daily C Fluxes for all Years of the Study (June 1998 to December 2001) and the Last 3 Years of the Study (June 1999 to December 2001)

\begin{tabular}{lcc}
\hline & June 1998 Through December 2001 $(n=1309)$ & June 1999 Through December 2001 $(n=944)$ \\
\hline NEE & model $=0.28+0.78 \cdot$ tower; $r^{2}=0.48$ & model $=0.30+0.86 \cdot$ tower; $r^{2}=0.48$ \\
ER & model $=0.17+1.44 \cdot$ tower; $r^{2}=0.87$ & model $=0.07+1.71 \cdot$ tower; $r^{2}=0.92$ \\
PSN & model $=-0.12+1.15 \cdot$ tower; $r^{2}=0.86$ & model $=-0.05+1.32 \cdot$ tower; $r^{2}=0.89$ \\
\hline
\end{tabular}




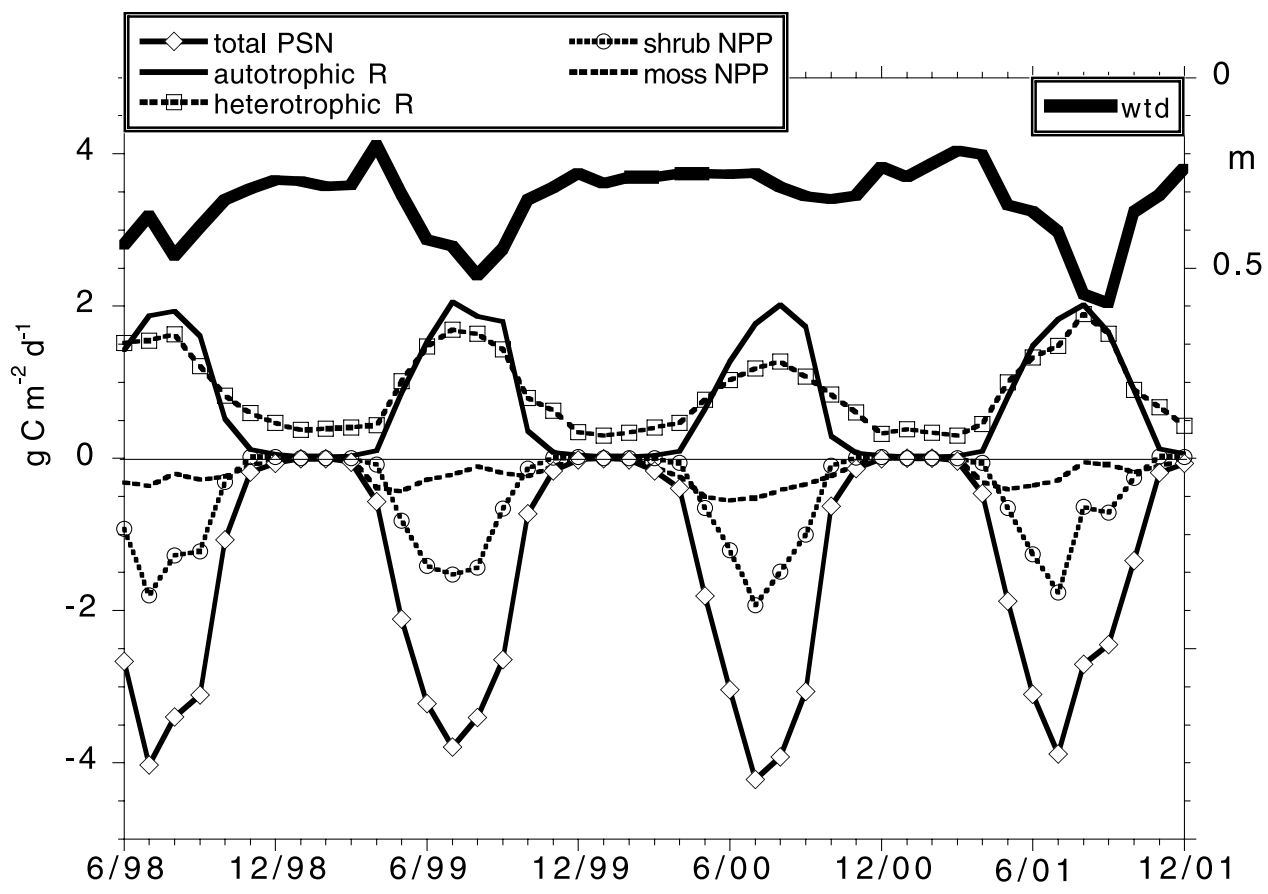

Figure 11. Observed monthly mean water table depth (thick solid line and right axis), and simulated monthly mean carbon exchanges; "total PSN" equals moss plus shrub gross photosynthesis, "autotrophic R" equals moss plus shrub (leaf, stem, and root) respiration, "heterotrophic R" equals peat decomposition lost as $\mathrm{CO}_{2}$, "shrub NPP" equals shrub photosynthesis minus shrub (leaf, stem, and root) respiration, and "moss NPP" equals moss photosynthesis minus moss respiration. Note that PCARS simulated that $\sim 95 \%$ of total decomposition was lost as $\mathrm{CO}_{2}$, the rest lost primarily as DOC, with a very small fraction lost as $\mathrm{CH}_{4}$.

until several weeks later and net $\mathrm{CO}_{2}$ accumulation was less rapid than for 2001. These results suggest that the environmental controls on dormancy and phenology and subsequent sequestration of $\mathrm{CO}_{2}$ are complex processes, which may not be captured adequately by PCARS's simple degreeday function approach to plant phenology.

\section{Conclusions}

[41] Our long-term observations on the surface-atmosphere $\mathrm{CO}_{2}$ exchange of the Mer Bleue Bog are in agreement with many results from previous peatland studies, but also highlight a few features not previously discussed, especially concerning the annual carbon budget. The magnitude of instantaneous and daily $\mathrm{CO}_{2}$ fluxes measured at Mer Bleue are in the range of results reported for eddy covariance measurements on other midlatitude and boreal peatland sites [Shurpali et al., 1995; Nieveen et al., 1998; Suyker et al., 1997; Joiner et al., 1999]. Fluxes from these sites tend to be somewhat higher than fluxes measured at subarctic and arctic peatland sites [Vourlitis and Oechel, 1997; Soegaard and Nordstroem, 1999; Aurela et al., 2001].

[42] Winter $\mathrm{CO}_{2}$ fluxes are an important component of the annual $\mathrm{C}$ budget. Our results show that for Mer Bleue, the winter $\mathrm{CO}_{2}$ loss can be as large as, and thus offset, 30-70\% of the summer $\mathrm{CO}_{2}$ gain. Snow cover and its influence on soil temperature can play an important role in determining the size of the winter flux. Winter eddy covariance measure- ments on peatlands are rare and most previous studies of the wintertime flux were short-term measurements by chamber or gradient techniques [Oechel et al., 1997; Fahnestock et al., 1999; Jones et al., 1999]. Winter $\mathrm{CO}_{2}$ flux at Mer Bleue was larger than found in these previous studies, but those studies were conducted in colder environments where decomposition would be expected to be severely limited by low temperatures.

[43] Our results support previous findings on peatland $\mathrm{CO}_{2}$ flux response to water deficits [Shurpali et al., 1995; Joiner et al., 1999; Alm et al., 1999]. We suggest that water table position is the most important determinant of interannual differences in peatland growing season NEE and therefore in the annual $\mathrm{CO}_{2}$ balance as well. The extended dry conditions in latter half of the 2001 summer severely reduced the sink strength of the peatland and resulted in the smallest growing season uptake of the 4 years studied. The wettest year of the study (2000) did not produce significantly larger fluxes than for the other 2 "normal" years. It is possible that any benefit to PSN afforded by the high water table was compensated for by a reduction in temperature and PAR during the wet summer. It is clear that the potential impact of climate change on the water balance of these ecosystems is a crucial question for future $\mathrm{C}$ balance research.

[44] Annual sequestration of $\mathrm{CO}_{2}$ in North American peatlands can be significant, $70-80 \mathrm{~g} \mathrm{CO}_{2}-\mathrm{C} \mathrm{m}^{-2} \mathrm{yr}^{-1}$ at Mer Bleue. This value is 3-5 times smaller than annual 
NEE measured at broadleaf deciduous forest sites in the boreal and northeastern hardwood forest zones [Barford et al., 2001; Barr et al., 2002]. It is, however, in the range of estimates reported for mature boreal conifer sites [Goulden et al., 1998; Malhi et al., 1999]. Therefore it is likely that peatlands, which are prevalent throughout the boreal zone, are an important contributor to carbon balance of that biome, and thus, should not be ignored in modeling studies of future $\mathrm{C}$ exchange.

[45] The PCARS model consistently overestimated ER and PSN, which offset one another to produce reasonable values of net ecosystem $\mathrm{CO}_{2}$ exchange compared to the flux tower estimates. While the causes of the bias between tower and model fluxes are unknown and are currently under investigation, the results of this study suggest that the general behavior of the PCARS model is likely correct and that the solution(s) might be achieved by reevaluating fundamental parameters, such as maximum PSN rate per unit foliar biomass and/or the base litter/peat decomposition rate. It is important to note that the constant discrepancy between tower and model has been attributed to model bias, but could also partly be attributed to tower bias as well. This provides an ongoing challenge, as the model calculates ER and PSN and then derives NEE, while the tower measures NEE and then derives ER and PSN. Thus model improvements should come from evaluating parameters controlling PSN and ER against independent direct measures of these processes, and not from calibration to tower-based estimates of PSN and ER. PCARS is shown to be a useful tool for separating ecosystem $\mathrm{C}$ fluxes into plant and soil processes.

[46] Acknowledgments. Funding for this project was provided by Natural Science and Engineering Research Council of Canada (Strategic Grant to N.T.R., P.M.L., and T.R.M.; and Research Grants to P.M.L. and N.T.R.), BIOCAP Canada Foundation (P.M.L. and N.T.R.), Climate Change Action Fund (N.T.R., P.M.L., and T.R.M.) and NASA's Terrestrial Ecology Program (S.F.) and Earth System Science Program (J.B.). We thank S. Admiral, D. van Dyk, and Robbie Hember for their assistance in the field and with data handling and processing. E. Whidden provided assistance with the spectral analysis of flux data. The National Capital Commission (NCC) of Ottawa kindly permitted use of the Mer Bleue site and G. Rother of NCC has provided much help and encouragement.

\section{References}

Alm, J., L. Schulman, J. Walden, H. Nykanen, P. J. Matikainen, and J. Silvola, Carbon balance of a boreal bog during a year with an exceptionally dry summer, Ecology, 80, 161-174, 1999.

Aubinet, M., et al., Estimates of the annual net carbon and water exchange of forests: The EUROFLUX methodology, Adv. Ecol. Res., 30, 113-175, 2000.

Aurela, M., T. Laurila, and J.-P. Tuovinen, Seasonal $\mathrm{CO}_{2}$ balances of a subarctic mire, J. Geophys. Res., 106, 1623-1638, 2001.

Baldocchi, D. D., et al., Fluxnet: A new tool to study the temporal and spatial variability of ecosystem-scale carbon dioxide, water vapor, and energy flux densities, Bull. Am. Meteorol. Soc., 82, 2415-2434, 2001.

Barford, C. C., S. C. Wofsy, M. L. Goulden, J. W. Munger, E. H. Pyle, S. P. Urbanski, L. Hutyra, S. R. Saleska, D. Fitzjarrald, and K. Mooreet, Factors controlling long- and short-term sequestration of atmospheric $\mathrm{CO}_{2}$ in a mid-latitude forest, Science, 294, 1688-1691, 2001.

Barr, A. G., T. J. Griffis, T. A. Black, X. Lee, R. M. Staebler, J. D. Fuentes, Z. Chen, and K. Morgenstern, Comparing carbon budgets of boreal and temperate deciduous forest stands, Can. J. For. Res., 32, $813-822,2002$

Black, T. A., W. J. Chen, A. G. Barr, M. A. Arain, Z. Chen, Z. Nesic, E. H. Hogg, H. H. Neumann, and P. C. Yang, Increased carbon sequestration by a boreal deciduous forest in years with a warm spring, Geophys. Res. Lett., 27, 1271-1274, 2000.
Bubier, J. L., P. M. Crill, T. R. Moore, K. Savage, and R. K. Varner, Seasonal patterns and controls on net ecosystem $\mathrm{CO}_{2}$ exchange in a boreal peatland complex, Global Biogeochem. Cycles, 12, 703-714, 1998.

Bubier, J. L., G. Bhatia, T. R. Moore, N. T. Roulet, and P. M. Lafleur, Between year and site variability in growing season net ecosystem $\mathrm{CO}_{2}$ exchange at a large peatland, Ontario, Canada, Ecosystems, in press, 2003.

Canadell, J., et al., Carbon metabolism of the terrestrial biosphere, Ecosystems, 3, 115-130, 2000.

Fahnestock, J. T., M. H. Jones, and J. M. Welker, Wintertime $\mathrm{CO}_{2}$ efflux from arctic soils: Implications for annual carbon budgets, Global Biogeochem. Cycles, 13, 775-779, 1999.

Falge, E., et al., Gap filling strategies for defensible annual sums of net ecosystem exchange, Agric. For. Meteorol., 107, 43-69, 2001.

Frolking, S., et al., Relationship between ecosystem productivity and photosynthetically active radiation for northern peatlands, Global Biogeochem. Cycles, 12, 115-126, 1998.

Frolking, S., N. T. Roulet, T. R. Moore, P. J. H. Richard, M. Lavoie, and S. D. Muller, Modeling northern peatland decomposition and peat accumulation, Ecosystems, 4, 479-498, 2001.

Frolking, S., N. T. Roulet, T. R. Moore, P. M. Lafleur, J. L. Bubier, and P. M. Crill, Modeling the seasonal to annual carbon balance of Mer Bleue Bog, Ontario, Canada, Global Biogeochem. Cycles, 16, 1030, doi:10.1029/2001GB001457, 2002.

Gorham, E., Northern peatlands: Role in the carbon balance and probable responses to climatic warming, Ecol. Appl., 1, 182-195, 1991.

Goulden, M. L., J. W. Munger, S.-M. Fan, B. C. Daube, and S. C. Wofsy, Measurements of carbon sequestration by long term eddy covariance: Methods and a critical evaluation of accuracy, Global Change Biol., 2, $169-182,1996$

Goulden, M. L., et al., Sensitivity of boreal forest carbon cycle to soil thaw, Science, 279, 214-217, 1998.

Griffis, T. J., W. R. Rouse, and J. M. Waddington, Interannual variability of net ecosystem $\mathrm{CO}_{2}$ exchange at a subarctic fen, Global Biogeochem. Cycles, 14, 1109-1121, 2000.

Hollinger, D. Y., S. M. Goltz, A. Davidson, J. T. Lee, K. Tu, and H. T. Valentine, Seasonal patterns in environmental control of carbon dioxide and water vapour exchange in an ecotonal boreal forest, Global Change Biol., 5, 891-902, 1999.

Joiner, D. W., P. M. Lafleur, J. H. McCaughey, and P. A. Bartlett, Interannual variability in carbon dioxide exchanges at a boreal wetland in the BOREAS northern study area, J. Geophys. Res., 104, 27,663-27,672, 1999.

Jones, H. G., J. W. Pomeroy, T. D. Davies, M. Tranter, and P. Marsh, $\mathrm{CO}_{2}$ in Arctic snow cover: Landscape form, in-pack concentration gradients, and the implications for the estimation of gaseous fluxes, Hydrol. Processes, 13, 2977-2989, 1999.

Lafleur, P. M., J. H. McCaughey, D. W. Joiner, P. A. Bartlett, and D. E. Jelinski, Seasonal trends in energy, water, and carbon dioxide fluxes at a northern boreal wetland, J. Geophys. Res., 102, 29,009-29,020, 1997.

Lafleur, P. M., N. T. Roulet, and S. W. Admiral, Annual cycle of $\mathrm{CO}_{2}$ exchange at a bog peatland, J. Geophys. Res., 106, 3071-3081, 2001a.

Lafleur, P. M., T. J. Griffis, and W. R. Rouse, Interannual variability in net ecosystem $\mathrm{CO}_{2}$ exchange at the arctic treeline, Arctic Antarct. Alp. Res., 33, 149-157, 2001b.

Malhi, Y., D. D. Baldocchi, and P. G. Jarvis, The carbon balance of tropical, temperate and boreal forest, Plant Cell Environ., 22, 715-740, 1999.

Massman, W. J., A simple method for estimating frequency response corrections for eddy covariance systems, Agric. For. Meteorol., 104, $185-$ 198, 2000.

Moore, C. J., Frequency response corrections for eddy correlation systems, Boundary Layer Meteorol., 37, 17-35, 1986.

Moore, T. R., J. L. Bubier, S. E. Frolking, P. M. Lafleur, and N. T. Roulet, Plant biomass and production and $\mathrm{CO}_{2}$ exchange in an ombrotrophic bog, J. Ecol., 90, 25-36, 2002.

Nieveen, J. P., C. M. J. Jacobs, and A. F. G. Jacobs, Diurnal and seasonal variation of carbon dioxide exchange from a former true raised bog, Global Change Biol., 4, 823-850, 1998.

Oechel, W. C., G. Vourlitis, and S. J. Hastings, Cold season $\mathrm{CO}_{2}$ emissions from arctic soils, Global Biogeochem. Cycles, 11, 163-172, 1997.

Oechel, W. C., G. L. Vourlitis, S. J. Hastings, R. C. Zulueta, L. Hinzman, and D. Kane, Acclimation of ecosystem $\mathrm{CO}_{2}$ exchange in the Alaskan arctic in response to decadal climate warming, Nature, 406, 978-981, 2000 .

Schindler, D. W., The mysterious missing sink, Nature, 398, 105-106, 1999. 
Schreader, C. P., W. R. Rouse, T. J. Griffis, L. D. Boudreau, and P. D. Blanken, Carbon dioxide fluxes in a northern fen during a hot, dry summer, Global Biogeochem. Cycles, 12, 729-740, 1998.

Shurpali, N. J., S. B. Verma, J. Kim, and T. J. Arkebauer, Carbon dioxide exchange in a peatland ecosystem, J. Geophys. Res., 100, 14,319$14,326,1995$.

Soegaard, H., and C. Nordstroem, Carbon dioxide exchange at a high arctic fen estimated by eddy covariance measurements and modelling, Global Change Biol., 5, 547-562, 1999.

Suyker, A. E., and S. B. Verma, Eddy correlation measurements of $\mathrm{CO}_{2}$ flux using a closed-path sensor: Theory and field test against an openpath sensor, Boundary Layer Meteorol., 64, 391-407, 1993.

Suyker, A. E., S. B. Verma, and T. J. Arkebauer, Season-long measurement of carbon dioxide exchange in a boreal fen, J. Geophys. Res., 102, 29,021-29,028, 1997.

Thormann, M. N., and S. E. Bayley, Above-ground net primary production along a bog-fen-marsh gradient in southern Alberta, Canada, Ecoscience, 4, 374-384, 1997.

Turunen, J., E. Tomppo, K. Tolonen, and A. Reinikainen, Estimating carbon accumulation rates of undrained mires in Finland-Application to boreal and subarctic regions, Holocene, 12, 69-80, 2002.

Vourlitis, G. L., and W. C. Oechel, Landscape-scale $\mathrm{CO}_{2}, \mathrm{H}_{2} \mathrm{O}$ vapour and energy flux of moist-wet coastal tundra ecosystems over two growing seasons, J. Ecol., 85, 575-590, 1997.
Waddington, J. M., and N. T. Roulet, Carbon balance of a boreal patterned peatland, Global Change Biol., 6, 87-97, 2000.

Webb, E. K., G. I. Pearman, and R. Leuning, Correction of flux measurements for density effects due to heat and water vapour transfer, $Q$. J. R. Meteorol. Soc., 106, 85-100, 1980.

Whiting, G. J., $\mathrm{CO}_{2}$ exchange in the Hudson Bay Lowlands: Community characteristics and multispectral reflectance properties, J. Geophys. Res., 99, 1519-1528, 1994.

J. L. Bubier, Environmental Studies Program, Department of Earth and Environment, Mount Holyoke College, South Hadley, MA 01075, USA. (jbubier@mtholyoke.edu)

S. Frolking, Institute for the Study of Earth, Oceans, and Space, University of New Hampshire, Durham, NH 03284-3525, USA. (steve. frolking@unh.edu)

P. M. Lafleur, Department of Geography, Trent University, 1600 Westbank Drive, P.O. Box 4800, Peterborough, Ontario K9J 7B8, Canada. (plafleur@trentu.ca)

T. R. Moore and N. T. Roulet, Department of Geography, Center for Climate and Global Change Research, McGill University, 805 Sherbrooke Street, West, Montreal, Quebec H3A 2K6, Canada. (moore@felix.geog. mcgill.ca; roulet@felix.geog.mcgill.ca) 